\title{
Sisko Savolaisen tukkimiehen kirjanpito
}

Kallion kirjaston lukinurkkauksessa on sen kahden ensimmäisen toimintavuoden aikana käynyt toista sataa henkilöä, jotka kaikki Sisko Savolainen on haastatellut kyselylomakkeen avulla. Sisko Savolaisen tukkimiehen kirjanpidossa on tiedot 116 lukinurkasta apua hakeneesta aikuisesta. Kävijöistä miehiä ja naisia on kutakuinkin yhtä paljon. On väitetty, että lukiongelmaisuus olisi kuitenkin miehillä yleisempi.

Apua hakeneiden koulutustausta on lähes tulkoon kaiken kattava. Ongelma esiintyy kaikilla koulutustasoilla ja kaikissa sosiaaliluokissa. Takana oleva tai senhetkinen koulutus suluissa olevine henkilömäärineen on seuraava: kansakoulu tai ei lainkaan koulutusta (9), peruskoulun ala-aste (17), yläaste (12), ammattikoulu (16), lukio (8), ylioppilas (28), opistotaso (31), tekninen koulu (4), korkeakoulu (10). Haastatelluista 31 sanoi ongelman esteeksi jatkaa opintoja ja 8 koki opintojen sen vuoksi viivästyneen. Reilu puolet tunnisti lukiongelman erittäin suurena esteenä opiskelulle: Mieli tekisi, muttei uskalla lähteä opiskelemaan.

Aineet, joissa ongelmat oli koettu, jakautuivat seuraavasti (116 vastaajalla):

96 kokee, että kirjoittaminen on vaikeaa

92 kokee, että lukeminen on erittäin hankalaa 56 koki musiikin vaikeaksi (lukiongelman ja musiikin yhteyttä ollaan selvittämässä, koska se on tullut esille arkipäivän kokemusten kautta)

50 koki voimistelun vaikeaksi

47 tunnisti kielelliset vaikeudet liittyen matematiikkaan

39 koki koulun pelit vaikeiksi

34 koki Piirtämisen vaikeaksi

30 kompastui kielestään käsitöihin 26 koki ongelmia kartanluvussa

23 ihmiselle matematiikka oli kokonaisuudessaan vaikeaa

12 koki matematiikan aluksi vaikeana, mutta pääsi myöhemmin siihen sisälle.

"Ne asiat - esimerkiksi voimistelu ja musiikki -jotka näitä lapsia ja aikuisia kuntouttaisivat kaikkein eniten, tippuvat ensimmäisenä pois. Motorinen hitaus nostaa suurimmaksi ongelmaksi ajan. Moni kokee pääsevänsä juuri alkuun, kun tunti jo loppuu. Etsin myös jotain 'punaista lankaa', muuta kuin lukemis- ja kirjoittamisvaikeudet, mikä yhdistäisi vastaajia. Mielestäni se on joukkuepelien pelaamisen vaikeus. Suurimman osan kokemuksissa se oli kärsimys, koska keho ei toiminut riittävästi ja muilta kuuli, 'ettei me oteta sua mukaan, kun sä mokaat meidän pelin'."

"Toinen, kenties kaikkein vaikein asia, on ollut kieltenopiskelu. Nekin, jotka ovat selvinneet jotenkuten lukemisesta, ovat hirttäytyneet viimeistään kieltenopiskeluun", kuvailee Sisko Savolainen."

Edellä olevassa keskustelussa kokemus sosiaalisista suhteista vaihteli isolla haitarilla. Kun jollakulla oli paljon kavereita, tunsi toinen olleensa aina yksinäinen. Sisko Savolaisen haastattelemasta 116 ihmisestä yli puolet, 64 henkilöä, tunnisti sosiaaliset vaikeutensa. Vastaan tässä tuli myös perhetausta. "Lukihäiriö ei synny perhetaustasta, mutta sen seuraukset voivat olla aivan erilaiset riippuen perhetaustasta", sanoo Sisko.

"Ihmiset itse sanovat ihmissuhteet kaikkein vaikeimmiksi asioikseen. Muita ovat sitten pitkänä listana asioiden hoitamattomuus, työttömyys, sairastaminen, epärehellisyys oman minän aitoutta tarkoittavassa mielessä, osaamattomuus, ajelehtiminen, osallistumattomuus, lukkiutuminen, pysähtyminen ammatillisessa kehityksessä, päihteet, itsetuhoinen käyttäytyminen, piiloutuminen, väkivalta, hitauden aiheuttamat hankaluudet, köyhyys, eristäytyminen, eristyminen, piiloutuminen kiltteyden taakse, pelko, uhman ja raivon taakse piiloutunut avuttomuus ja toivottomuus, häpeä, voimattomuus, masennus, liiallinen yrittäminen, 
tekemättä jättäminen, torjunta, liika kiltteys tai huono käytös, kostaminen, varuillaanolo, raivo, viha ja kateus."

"Liika yrittäminen ja kiltteys ovat itse asiassa vakavampi asia kuin käytöshäiriöt. Käytöshäiriöinen osaa edes jollakin tavalla osoittaa sen, että voi huonosti ja homma ei toimi. Kiltti ei. Kiltit ihmiset ovat vaikeasti autettavia, eikä päälle päin näy mitään häiriötä. Häpeäntunne on jännä ilmiö. Ihmiset, jotka ovat olleet koulussa ennen 70-lukua, muistavat syvän häpeän ja syyllisyyden pärjäämättömyydestään. Nuoret eivät taas tunnista koko häpeää."

"Lukiongelmaiset ovat tehneet omien kouluja elämänkokemustensa pohjalta runsaasti ehdotuksia, joilla lisättäisiin yhteiskunnassa, ennen muuta opettajien ja päättäjien keskuudessa tietoa heidän ongelmistaan ja ymmärrystä niiden lievittämiseksi."

\section{MISTÄ HAKEA APUA?}

\section{Lukikursseja järjestävät kansalaisopistot:}

Ahjolan kansalaisopisto, Tampere (931) 549 711; Espoon suomenkielinen työväenopisto, (90) 517 022; Helsingin kaupungin suomenkielinen työväenopisto , (90) 731233 ja Turun suomenkielinen työväenopisto (921) 2322320

\section{Lukikoulutusta järjestävät kansanopistot:}

Kruunupyyn kansanopisto (968) 8345017 (ruotsinkielinen)

Portaanpään kristillinen kansanopisto, Lapinlahti (977) 31441.

Turun kristillisen opiston Luki-Tuki -keskus, Tarja Penttilä, puh. (921) 638001

\section{Muita oppilaitoksia:}

Käpylän iltaoppikoulu, Anna-Maija Hintikka (90) 492 552, koti (90) 791930 (oppimisongelmaisten mahdollisuus peruskoulunkäyntiin)

Turun ammatillinen aikuiskoulutuskeskus, Rauno Laine (921) 2341422 (Pohjoismaisen VOKS NÄR -ohjelman Suomen osuus koskien aikuisten oppimisvaikeuksia; erilaista toimintaa oppimisongelmaisten parissa Turussa)

\section{Järjestöjä ja kirjastoja:}

Helsingin seudun erilaiset oppijat ny. Airi Valkama, puh. (90) 14802013

Kallion kirjastossa Vapaan Sivistystyön Yhteisjärjestön Lukinurkkaus, Sisko Savolainen, puh. 73124483 (avoinna ma ja ti kello 17-20 sekä ke ja to kello 13-16)

Työväen Sivistysliitto, Helvi Ollikainen (90) 708981 (lukiongelmaisten kursseja, neuvontapalvelua ja selkokirjallisuutta)

Vapaan Sivistystyön Yhteisjärjestö, Eeva Siirala (90) 441209 (neuvontaa ja toiminnan seurantaa)

\section{Tutkimus- ja kehittelytyötä:}

Turun yliopiston oppimistutkimuksen keskus (921) 63381 (Ottaa vastaan asiakkaita oppimisvaikeuksien diagnoosia ja terapiaa varten kohderyhminä lapset; oppimisvaikeuksien tutkimuskeskus)

Niilo Mäki Instituutti Jyväskylän yliopiston psykologian laitos (941) 602 907/ koulutus ja tiedotus (Tutkimuskeskus, jonka keskeisenä tutkimusalueena on lukemisen, kirjoittamisen, matematiikan ja tarkkaavuuden häiriöiden neuropsykologinen perusta; tietokoneavusteisen diagnosointi- ja kuntoutusmenetelmien kehittäminen) 